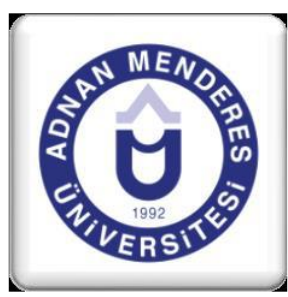

\title{
Kentsel Yenileme Sürecinde Kentsel Tasarımın Önemi: Aydın-Söke Örneği
}

\author{
Özkan ADÍLHAN ${ }^{1}$, Levent ÜNVERDí ${ }^{2}$
}

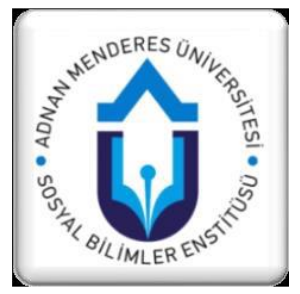

\section{ÖZET}

Ülkemizin şehircilik konusunda fazla bir gelişim gösteremediği ve sürecin istenen şekilde yönetilemediği, farklı çevrelerce kabul edilen bir gerçektir. 3194 Sayılı İmar Kanunu ve bu kanuna bağlı ilgili yönetmeliklerin kentlerin mekânsal değișim ve dönüşümünde sınırlı sayılabilecek bir etkide bulunması, farklı araçların sürece dâhil edilmesi gerekliliğini ortaya koymaktadır. Bu araçların en temelinde ve merkezinde ise kentsel tasarım kavramı yer almaktadır. Bu çalışmada, ülkemizde yıllardır süregelen ve hala devam eden çarpık kentleşme sorununun, kentsel yenileme kavramı özelinde değerlendirilerek, yenilemenin kentsel tasarım ile birlikte kurgulanması gerekliliği üzerinde durulmuştur. Kentsel tasarım kavramının, planlama süreci içerisinde, etkin bir araç olarak kullanılması ve süreci yönlendirmeye yönelik katkı sağlaması yönünde Söke Belediyesi'nce yapılan çalışmalar örnek olarak seçilmiştir. Söke Belediyesi'nce yapılan çalışmalarda mevcut sorunların onaylı alt ölçek plan kararları ile çözümünün mümkün olamayacağı ve klasik planlama anlayışıyla parsel ölçeğinde plan tadilatları ile de çözülemeyeceği fark edilerek, kentsel tasarım ölçeğinden başlayıp kentsel yenileme esaslı imar planlarının elde edilmesi stratejisi ve yarışma yönteminin benimsenmiş olması Söke'nin örnek çalışma alanı olarak seçilmesini nedenlemiştir. Bu kapsamda Söke Belediyesi'nce yapılan çalışmalar özelinde, kentsel yenileme, kentsel tasarım ve planlama sürecinin nasıl yönetildiği açıklanmış ve bu süreçte ortaya çıkan sorunlarla birlikte çözüm yollarının neler olabileceği hususunda öneriler geliştirilmiştir.

Anahtar Kelimeler: Söke, kentsel yenileme, kentsel tasarım

\section{The Role Of Urban Design in Urban Renewal Processes; Case of Söke/Aydın}

\section{ABSTRACT}

It is a fact accepted by different circles that our country could not make much progress in the subject of urbanization and that the process could not be managed much in a desired manner. Limited effect of our existing laws and regulations, especially the Construction Law numbered 3194 and the related regulations, on the spatial change and transformation has revealed the necessity for including different tools in the process. However, the urban design concept takes the most fundamental and central place among these tools. Departing from evaluation of the long-established and still ongoing-irregular urbanization which have strong links with the urban renewal processes in our country, this study dwells upon the necessity to adopt urban renewal strategies in urban design, The works carried out by the Municipality of Söke have been selected as a unique case where urban design concepts are used as effective tools in the planning process and contribute for directing and managing the entire process. In works of Söke Municipality, considering that solving the social and technical infrastructure and environmental problems must be evaluated primarily together with the existing structural problems and that plan amendments on parcel scale cannot be of any remedy in planning decisions, the main strategy has been to obtain urban renewal-based development plans ranging from urban design scale to upper scales and the method in this strategy is through competition. In this respect, case of Söke appears unique in terms of strategy and method both. In line with this, specific to the works carried out by the Municipality of Söke, the ways of how urban renewal, urban design, and the related planning processes are managed has been explained and the concluding suggestions address to not only on the problems occurred in this process, but also possible ways of alternative solutions.

Key Words: Söke, urban renewal, urban design

${ }^{1}$ Dokuz Eylül Üniversitesi, Fen Bilimleri Enstitüsü, Şehir ve Bölge Planlama Ana Bilim Dalı, Yüksek Lisans Öğrencisi

${ }^{2}$ Öğr. Gör. Dr. Dokuz Eylül Üniversitesi Mimarlık Fakültesi Şehir ve Bölge Planlama Ana Bilim Dalı

*Bu makale, Dokuz Eylül Üniversitesi Fen Bilimleri Enstitüsü’nde tamamlanmış olan "Kentsel Yenileme Sürecinde Kentsel Tasarımın Önemi: Aydın-Söke Örneği” adlı yüksek lisans tezinden hazırlanmıştır. 


\section{Giriş}

Büyük kentler başta olmak üzere, kentlerimizin genelinde kimliksizleşen, niteliksiz fiziksel çevrelerin, sağlıksız yapılaşma ile birlikte arttığı ve bu olumsuzlukların ekonomik cansızlığa ve cazibesini yitirmeye başlayan kentsel alanların ortaya çıkmasına neden olduğu bilinmektedir. Bu olumsuz sürecin kentsel yenileme uygulamaları ile yönetilmesi ve sorunun doğru tespit edilerek doğru teşhisle kentlere müdahale edilmesi gerekmektedir. Bu müdahale sürecinde yenileme kavramının yanında kentsel tasarım kavramının da planlama ile birlikte değerlendirilmesi çalışmanın ana bileşenini oluşturmaktadır.

Yıpranan ve köhneme riski ile karşı karşıya kalan kentsel alanların, tekrar canlandırılması ve bu alanlarda yaşam kalitesinin arttırılması, fiziksel mekânın değişen koşullar ve kullanıcı tercihleri doğrultusunda iyileştirilmesi, kentsel tasarım ilkelerinin ve standartlarının belirlenmesi ile mümkün kılınabilir. Kentsel yenileme yapılacak alanlar için, kendine özgü tasarım ilkelerinin geliştirilmesi ve bunun kentsel tasarım rehberleri ile desteklenmesi tasarımın başarıya ulaşma noktasında olumlu bir süreç olacaktır.

Yürütülen çalışma, kentsel yenileme alanı olarak belirlenen alanlarda mevcut planlama pratiği çerçevesinde öngörülen plan kararlarının tek başına yeterli olamadığı, plan kararlarının kentsel tasarım ve kentsel tasarım rehberleri ile birlikte desteklenerek kurgulanması gerekliliğini ortaya koymak üzere yapılmıştır.

\section{Kentsel Yenileme - Kentsel Tasarım Kavramları ve İlișkisi}

1950'lerde sefalet yuvaları diye adlandırılan “slum' 'ların (çöküntü alanları) temizlenmesiyle başladığı bilinen (Andersen, 1999) kentsel yenileme kavramı, zaman içerisinde çok farklı disiplinlerin farklı yaklaşımlarıyla ele alınmıştır. Bir tanıma göre yenileme, "mevcut kentleri ve merkezleri düzeltmek ve günün gereklerine uydurmak amaciyla yeniden planlama ve bunu uygulama" olarak tanımlanmıştır (Hasol, 1998). Başka bir tanımlamada ise "zaman içinde eskimiş ve yıpranmış kent dokularının, günün sosyal ve ekonomik şartlarına uygun olarak değiştirilmesi veya yenilenmesini sağlayan süreçtir" şeklinde ifade edilmiştir (Atalık ve diğ., 1985).

Genel bir yaklaşımla, kentsel yenileme, farklı dönemlerde ve çok farklı gerekçelerle kentlerin çeşitli faktörler neticesinde çöküntüye uğraması sonucu, kente yapılan fiziksel, sosyo-kültürel ve ekonomik anlamda yapılan müdahalelerin bütünüdür, denebilir. $\mathrm{Bu}$ müdahale, bazen köhnemiş ve yıpranmaya yüz tutmuş kent merkezlerine olabildiği gibi, bazen de işlevsizleşen sanayi alanlarının kente tekrar kazandırılması yönünde olabilmektedir.

Diğer bir ifade ile kentsel yenileme;

"Kamu girişimi ya da yardımıyla, yoksul komşuluklarının temizlenmesi, yapıların iyileştirilmesi, korunması, daha iyi barınma koşulları, tecim ve işleyim olanakları, kamu yapıları sağlanması amacıyla, yerel tasar ve izlenceler uyarınca, kentleri ve kent özeklerinin tümünü ya da bir bölümünü, günün değişen koşullarına daha iyi yanıt verebilecek duruma getirmek" olarak tanımlanmaktadır (Keleş, 1980). Söz konusu tanımlamalardan da anlaşılacağı üzere, kentsel yenileme bozulan ve işlevsizleşen fiziksel çevrenin, tekrar eski 
kimliğine veya günümüz sosyal, ekonomik şartlarına uyum sağlayacak seviyeye getirmek için yapılan iyileştirme çabasıdır.

Kentsel tasarım terimi ise ilk kez 1920'li yıllarda Amerika'da kurulan Kentsel Tasarım Komitesi'nde kullanılmıștır. Amerikan Mimarlar Birliği (A.İ.A) bünyesinde kurulan komitede, mimarlar ve kent plancıları deneyim ve görüşlerini paylaşarak katkıda bulunmuşlardır. Ancak, tanımın kavramsal ve bilimsel olarak gelişimi, 1956 yılında Harvard Üniversitesi'nin açı1ış konferansı ve diğer konferanslarda, gerek kent plancılarının gerekse de tasarımcıların yaptıkları değerlendirme ve tartışmalarda ortaya çıkmıştır.

20. yüzyılın ilk yarısında modernizm, mekânı değiştirirken katı nesnel ve rasyonel kurallar ile oluşmuş tekdüze, kimliksiz daha çok sanayi devriminin etkisiyle üretilen kentsel alanların üretimine neden olmuştur. Kentsel tasarım, bu sürece karşı gelecek şekilde ve farklı disiplinler arasında, ama esas olarak planlama, peyzaj mimarlığ birleştirici bir alt disiplin olarak akademik camia tarafindan yapılan değerlendirme ve tartışmalar sonucu ortaya çıkmıştır. Kavramsal tanımlarda çok farklı yaklaşımlarda bulunulmasına rağmen, temelde yaşanılabilir kentsel çevreler yaratılması ve yaşam kalitesinin yükseltilmesi ortak hedef olarak belirtilmiştir.

Kentsel tasarımı disiplinler arası boyutta değerlendirenlerden olan Shirvani’ye göre kentsel tasarım; mimarlık, peyzaj mimarlığı, şehircilik, inşaat ve ulaşım mühendisliği, psikoloji, hukuk, gayrimenkul gelişimi ve diğer ilgili disiplinleri barındıran karmaşık disiplinler arası bir alandır (Günay,1999). Maria Auböck, 'Open Spaces-The City' adlı kitabında; kentsel tasarımın, kentsel plan ve mimari proje arasında yer alan, iki dünya arasında köprü niteliğinde, yeniden canlanan bir disiplin olarak tanımlar. Ona göre kentsel tasarım, kısmen plan, kısmen projedir, kamusal-kentsel mekân strüktürünü tanımlayan süreç içinde estetik ve yasal araçtır (Auböck, 1996). Şehir plancısı Günay'a göre kentsel tasarım; makro, meso ve mikro ölçeklerde kentin form ve yaşamını üretme teori ve pratiğidir. Planlama kararlarının gerçekleştirme süreci ve kentsel çevrenin yaratılmasıdır (Günay, 1999).

Kentsel yenileme ve kentsel tasarım kavramlarına ilişkin bu tanımlamalardan da görüleceği gibi kentsel yenilemenin önemli bir parçasını tasarım oluşturmaktadır. İşlevsizleşmiş ve köhneleşmiş kentsel parçaların tekrar canlanması ve hayata geçirilmesi kentsel tasarım uygulamaları ile mümkün olabilecektir. Kaldı ki kentsel tasarımın, ana hedefleri arasında kentsel mekânların iyileştirilerek yaşam kalitesinin yükseltilmesi ve kullanıcıların gereksinimlerini kolaylaştıracak ve estetik kentsel mekânların oluşturulması yer almaktadır. Bu kapsamda kentsel yenileme ile doğrudan bağlantısı olan kentsel tasarımın, yenileme sürecinde baş aktörler arasında yer alması kaçınılmazdır. Kentsel yenileme yapılacak alanlar için, kendine özgü tasarım ilkelerinin geliştirilmesi ve bunun kentsel tasarım rehberleri ile desteklenmesi tasarımın başarıya ulaşma noktasında olumlu bir süreç olacaktır.

Katılımcı, bütüncül ve uygulanabilir bir kentsel tasarım projesi, yenileme alanında bulunan taşınmazlara da değer artışı sağlayacağ 1 bir gerçektir. Ancak bu sonucun mevcut çalışma alanı içerisindeki mülkiyet sahiplerince de kabul görmesi, proje sonrasında oluşacak olan değer artış kazancının eşitlik ilkesi çerçevesinde paylaşım esasına dayanmaktadır. $\mathrm{Bu}$ eşitlikçi paylaşım ilkesi, katılımcı bir sürecin önünü açacaktır. Uygulama sürecindeki en temel sorun olarak görülen katılımcı seviyesi ve finansal boyut, kentsel tasarımın yenileme alanına katacağı değer artışıyla aşılacaktır. 
Kentlerde, daha çok merkezi yerleşik dokuda, kent merkezlerinde küçük ve çok hisseli parsellerin bulunması yine benzer şekilde gecekondu mantığı ile yapılaşan alanlarda, mülkiyetin mevcut yapıya uydurulması sonucu çok küçük ve biçimsiz parsellerin oluşmasına neden olmuştur. Daha sonraki süreçte imar afları ile birlikte bu yapılaşmalar yasal bir zemine oturtulmuştur. Bunun sonucunda mevcut yapılara göre oluşturulan küçük parsellere tapu verme süreciyle mülkiyetler parçalanmıştır. Halen pek çok kentte, kent merkezine yakın lokasyonlarda konumlanmış ve islah imar planları ile yapılaşma sürecine devam eden bölgeler bulunmaktadır. Bu yapılaşma süreci yıllar önce imar afları neticesinde kazanılmış olan mülkiyetler üzerinde devam etmekte ve kent merkezlerine yakın konumlarda bulunan bu bölgeler, yine benzer şekilde niteliksiz, kimliksiz, yeterli altyapı ve sosyal donatı alanlarını barındırmayan kentsel alanların devamına neden olmaktadır. İlginçtir ki, ilgili yerel idarelerde bu yapılaşma sürecinin devamına engel olmamaktadırlar. Kentlerin değerli olarak nitelendirilen bölgeleri içerisinde kalan bu alanlarda, kentsel yenileme uygulamalarının, kentsel tasarım projeleri ile desteklenmesi, söz konusu alanların kente tekrar kazandırılması yönünde olumlu bir kazanım olacaktır. $\mathrm{Bu}$ açıdan da değerlendirdiğimizde, kentsel yenileme ve kentsel tasarım birbirlerini tamamlayan iki ayrı unsur olarak karşımıza çıkmaktadır.

Halen Türkiye'deki planlama pratiğine bakıldığında, ülkemizin kentsel mekândaki değişimin yönetilmesi konusundan çok uzak kaldığı görülmektedir. Klasik imar anlayışı ve parsele endeksli planlama kurgusu, esneklikten uzak olduğu gibi, estetikten de uzak bir yaklaşım sergilemektedir. Süregelen planlama sisteminin, ada veya parsele tanımlanan fonksiyon, yapılaşma koşulu ve çekme mesafeleriyle tariflenen bir kısır döngü içerisindedir.

Özellikle kentlerin gelişme alanlarında, onaylı imar planlarına göre yapılması esas olan imar uygulamalarının çok farklı nedenler ile hayata geçirilemediği ve bu planlı gelişmesi öngörülen alanların tevhid, ifraz, yola terk, yoldan ihdas gibi uygulama araçları ile çözümlenmeye çalışılması, kadastral parsele esas yapılaşmaların önünü açmaktadır. $\mathrm{Bu}$ durum ise, kentsel mekânın biçimlenmesine ve değişiminin yönlendirilmesine çok az katkısı olan planlama ilkelerinin tamamen soyutlanmasına neden olmaktadır. Kentsel mekândaki değişim, tasarım ilkeleri ile birlikte denetlenerek yönlendirilmesi gerekirken, mevcut sistemin bu denetim ve yönlendirmeden çok uzak olduğu görülmektedir. Parsele dayalı anlayış, bütüne baktığımızda tasarımdan yoksun tek tip planlar ortaya çıkartmaktadır. $\mathrm{Bu}$ planlar, kentsel mekân oluşumundan ve yapıların birbirleriyle ve çevresiyle olan ilişkilerinin kurgulanmasından uzak, parsellerin oluşturduğu imar adalarından oluşmaktadır. Bu durum ise kimliksiz ve niteliksiz kentsel alanların oluşmasına neden olmuştur. Kentsel mekânın biçimlenmesinde, tasarım denetimini ön plana çıkaran bir mekanizmanın olmayışı sürecin günümüze kadar devam etmesinde etkin rol oynamaktadır.

Görülmektedir ki, yenileme eyleminin mevcut mülkiyet dokusuna bağlı kalarak gerçekleştirilmesi, kentsel tasarım kavramının önündeki en büyük çıkmaz olarak karşımıza çıkmaktadır. Bu nedenle mülkiyet dokusunun, kentsel tasarım projeleri çerçevesinde şekillendirilmesi ve geri beslemeli olarak uygulama imar planlarına aktarılarak yasal zeminde karşıllk bulması gerekmektedir. Bu nedenle kentsel yenileme ve kentsel tasarım kavramları birbirlerini tamamlayan ve birlikte yürütülmesi gereken eylemlerdir. 


\section{3. Ülkemizde Kentsel Yenileme ve Kentsel Tasarıma Bakış}

Ülkemizde kentsel yenileme konusunda, yasal yönetsel ve işlevsel anlamda tutarlı bir politikanın geliştirilemediği, geçmişten günümüze gelen planlama pratiği çerçevesinde, kentlerimizin tasarımdan ve estetikten yoksun klasik imar planı kurgulanmaları ile şekillendiği görülmektedir.

Öncelikle Türkiye'de kentsel yenileme uygulamalarına bakıldığında, büyük alanları içerisine alan, bütüncül olarak kentin diğer parçaları ile de uyumlu kentsel yenileme çalışması deneyimlerinin pek fazla bulunmadığı görülmektedir. 2004 yılında yapılan yasal düzenleme sonucu Toplu Konut İdaresi'nin, yenileme ve dönüşüm projelerinde etkin rol alan ve süreci yöneten kurum olarak karşımıza çıkmasından önce Ankara'da gerçekleştirilen "Portakal Vadisi Projesi ve Dikmen Vadisi Projesi" ile başlayan kentsel yenileme uygulamaları, 2004 sonrası süreçte Toplu Konut İdaresi ile birlikte daha çok, orta ve alt sınıf konutlar üretmek amacıyla arsa üretme politikası biçiminde gelişmiştir. 16.05.2012 tarihinde kabul edilerek 31.05.2012 tarih ve 28309 say1lı Resmi Gazete'de yayımlanan 6306 sayıl1 Afet Riski Altındaki Alanların Dönüştürülmesi Hakkında Kanun'dan sonra hızla konut üretme politikasının hakim olması ile birlikte proje alanı içerisinde yer alan toplumsal sorunlar, alanda yaşayanların beklenti ve talepleri göz ardı edilmiş, pek çok mahalle sakini, kent çeperlerinden rezerv alan olarak ayrılmış, genellikle hazine arazilerinin tercih edildiği alanlarda üretilen toplu konutlara yerleştirilmişlerdir.

Kentsel dönüşüm/yenileme kapsamında üretilen toplu konut projelerinde kent bütününe yönelik gerekli yer seçimi kriterleri göz ardı edilerek, yer seçiminin sadece hazine arazisinin varlığı üzerine odaklanması, kentlerin parçalanmasına ve kamu yatırımlarından optimum verim alınamamasına neden olmaktadır. Bunun temel nedenleri arasında, siyasi iradenin en kısa yoldan ve kamulaştırma yapmadan, sonuca ulaşmak isteği ile bürokrasinin de siyasi iradeye karş1, verilen görevi en kısa sürede yerine getirme isteği bulunmaktadır. Kentsel yenileme projelerinde özel sektörün yer seçimi konusunda herhangi bir tercihi veya seçeneği bulunmamakta, üretilen konut projelerinden elde edilen karın miktarı ve ne kadar sürede geri döneceği konuları konut üretiminde temel belirleyici olmaktadır. Bu nedenle de gerçek anlamda kentsel yenileme projelerinde özel sektör girişimleri azalmaktadır. Yenileme projelerinde kısa sürede yatırımın kara dönüşmesini riskli görmeleri ve sadece yapısal anlamda değil sosyal içeriğinin de titizlikle ele alınması gerekliliği özel sektör yatırımcıları için tedirginlik oluşturmaktadır. Bu nedenle, rant değeri yüksek kent merkezlerinde, kentsel yenileme adı altında, parsel bazında dönüşüm seçeneklerini öncelikli olarak değerlendirdikleri görülmektedir. Bu durum ise mekânsal anlamda bütünsellikten uzak, fiziksel ve sosyal açıdan ise beklentilerin karşılanamamasına neden olmaktadır.

Son yıllarda yazılı ve görsel basında, özellikle gayrimenkul yatırımcıları, parsel bazında değil, ada bazında dönüşüm ve yenilemeyi sıklıkla dile getirmektedir. Bu söylem, kentsel yenileme ve dönüşümde hala planlama gerçeğinden uzak kalındığını ve planlamanın bu sürece dâhil edilmediğini göstermektedir.

Diğer önemli bir konu ise, Tekeli'nin (1998) de ifade ettiği gibi ikinci dünya savaşından günümüze kadar devletin konut politikasına bakış açısının değişmemesidir. Genellikle konut politikası yaşanan ekonomik krizlerin aşılmasında bir aktör olarak görülmüştür ve hala da görülmeye devam etmektedir. Konut üretiminin pek çok yan sektörlerin de katkısıyla, ekonomide yaşanan olumsuzluklara geçici bir çözüm olarak görülmesi, hızlı ve kontrolsüz 
kentleşme sürecini de olumsuz yönde etkilemektedir. Ayrıca, devletin konut üretimine yönelik 1lımlı yaklaşımı, yasal ve finansal anlamda göstermiş olduğu kolaylıklar, sanayi ile birlikte üretim sektörünün çekiciliğini azaltmakta, üretime dayalı büyüme modelinden gayrimenkul odaklı büyüme modeline geçişi hızlandırmaktadır. Bu politika ise, uzun yıllardır sanayi sektöründe olan sermayenin gayrimenkul sektörünün cazibesine kapılarak sektörel değişime gitmelerine neden olmaktadır.

Bu bakış açısının değişmesi gerektiği yönünde pek çok profesyonel, akademisyen, eleştirel yaklaşımlarını farklı platformlarda ifade etmişlerdir. Kentlerimizin şu an geldiği durum bu eleştirel yaklaşımların haklılığını da göstermektedir. Bu nedenle, planlama pratiğinde farklı arayışlara geçilmiş, ancak halen ülkemizde yasal ve yönetsel boyutta bu değişim gerçekleşememiştir.

Ülkemizde, kentsel tasarım kavramına yönelik tartışmaların 1970'li yıllarda akademik araştırmalar çerçevesinde ele alınarak başladığı görülmektedir. Bu süreci meslek odalarının da desteklemesi ve yerel idarelerce açılan proje yarışmaları kentsel tasarım kavramının ülkemizde tanınmasına katkı sağlamıştır. Bu süreçte özellikle ulusal ölçekte büyük projeler düzenlenmesi yönünde girişimlerde bulunan yerel idarelerin bünyelerinde kentsel tasarım birimleri kurulmuştur. 1983 yılında ise YÖK tarafindan yapılan yeni düzenleme ile kentsel tasarım üniversiteler bünyesinde yüksek lisans ve doktora programlarına dâhil edilerek farklı bir alt disiplin olarak tescil edilmiştir. Bu süreçten sonra, hem üniversiteler bünyesinde ayrı bir uzmanlık alanı olarak yüksek lisans ve doktora programları devam etmiş hem de yerel idarelerce yürütülen ve açılan proje yarışmaları sürdürülmüştür. Kentsel tasarım kavramı ilk kez merkezi yönetim bünyesinde 2011 yılında kurumsallaşmıştır. 2011 yılında Çevre ve Şehircilik Bakanlı̆̆g’nın kurulmasıyla, Mekânsal Planlar Genel Müdürlüğü, bakanlığın kurumsal yapısında yerini almıştır. Aynı genel müdürlügün bünyesinde ise Kentsel Tasarım Dairesi Başkanlığı oluşturulmuştur. Kentsel Tasarım Dairesi Başkanlığı'na ise; Kentsel Tasarım Şube Müdürlüğü, Marka Şehirler Şube Müdürlüğü ve Proje Yönetim Şube Müdürlüğü bağlanmıştır.

2014 yılında yürürlüğe giren Mekânsal Planlar Yapım Yönetmeliği’nde, kentsel tasarım ilk kez bir mevzuat kapsamında değerlendirilmiş ve "Kentsel Tasarım Projelerine Dair Esaslar" başlığı ile mevzuatta ki yerini almıştır. Ancak tüm bu düzenlemelere karşın kentsel tasarım kavramının, henüz birçok yerel idarenin kurumsal yapısında bile yer bulamadığ görülmektedir. Kurumsal yapılarında yer veren yerel idareler arasında ise yaklaşık yarısının kavramın iyi anlaşılamaması nedeniyle, kurumsal yapılarında yanlış konumlandırdıkları görülmektedir.

$\mathrm{Bu}$ kapsamda ülkemizde 81 belediyenin resmi internet sayfalarından alınarak hazırlanan veriler doğrultusunda ortaya çıkan sonuçlar, bu yargıyı doğrular niteliktedir. Şekil 1'de görüldüğü üzere büyükşehir statüsünde olmayan 51 il belediyesinden, sadece 5 ilimizde Kentsel Tasarım ile ilgili birim bulunurken, Kent Estetiği ile ilgili herhangi bir yapılanmanın olmadığ1 görülmektedir. Söz konusu tespitler büyükşehir belediyeleri özelinde ele alındığında da farklı bir sonuçla karşılaşılmamaktadır. Toplam 30 büyükşehir belediyesinden 11 tanesinde kentsel tasarım ve kent estetiği kavramlarına kurumsal yapılanma içerisinde yer verilmediği görülmektedir. Kurumsal yapılanmalarında yer veren belediyelerden ise, toplam 9 tanesinin Kent Estetiği, 5 tanesinin Kentsel Tasarım, 5 tanesinin ise her iki kavramı da kurumsal yapılanmalarına dâhil ettiği izlenmektedir (Şekil 2). 


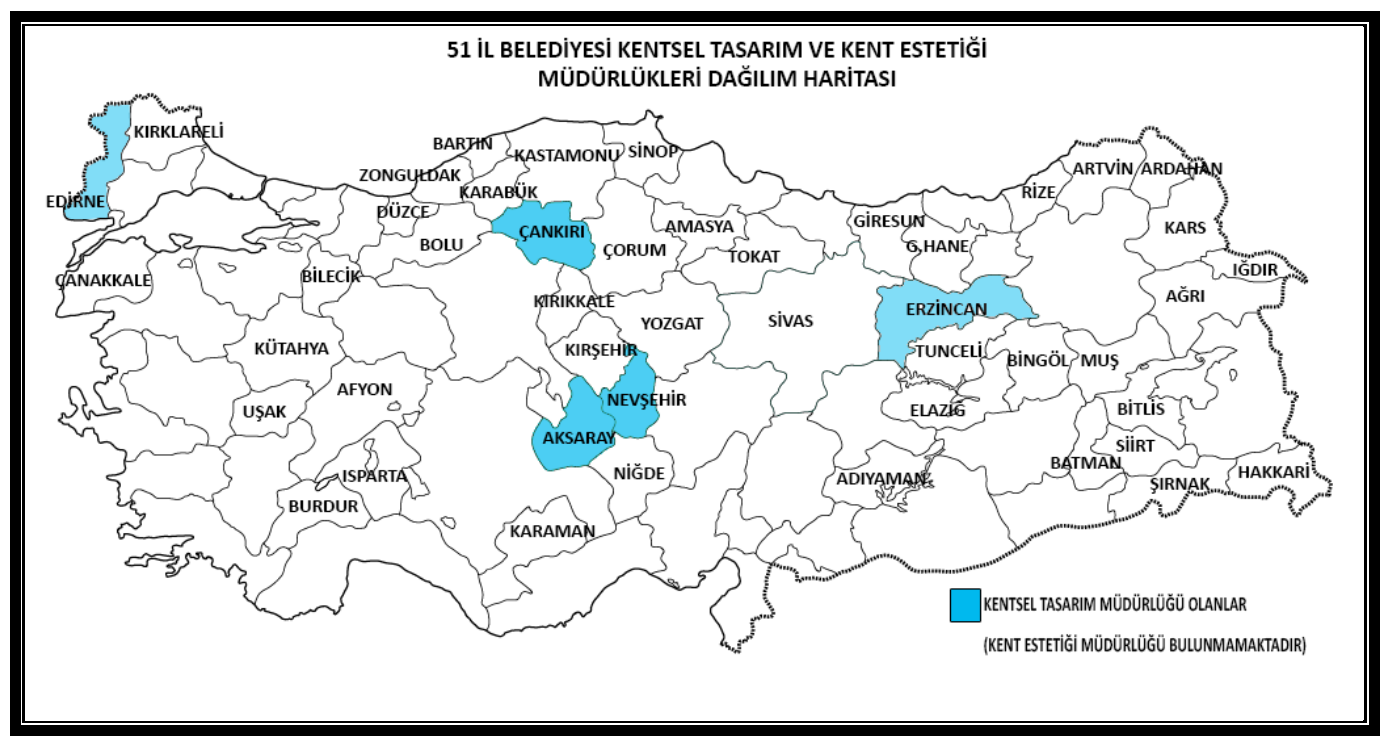

Şekil 1 İl belediyeleri geneli durum (Belediyelerin resmi internet sayfalarından alınan veriler doğrultusunda Yazar tarafindan oluşturulmuştur)

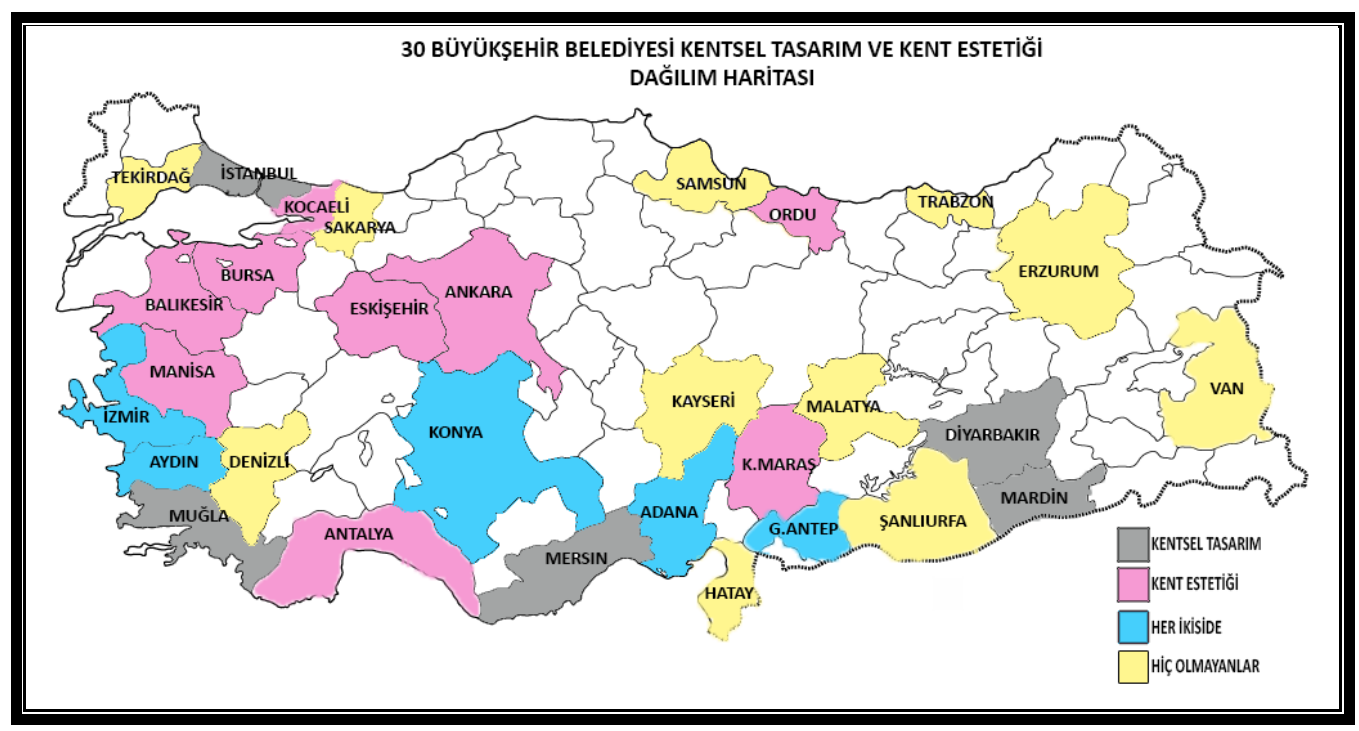

Şekil 2 Büyükşehir geneli durum (Belediyelerin resmi internet sayfalarından alınan veriler doğrultusunda Yazar tarafindan oluşturulmuştur)

Bu aşamada Çevre ve Şehircilik Bakanlığı'nca ilgili idarelere "tasarım rehberi hazırlama yöntemi” nin öğretilmesi amacıyla "Kentsel Tasarım Rehberlerinin Hazırlanması Projesi"ne ilişkin çalışmalar tamamlanmışsa da, ülkemiz yerel idarelerindeki mevcut kurumsal yapılanma karmaşası ve birim sorumlusu mesleki yetkinlik düzeyleri, bu projenin başarıya ulaşmasında, potansiyel bir sorun olarak karşımıza çıkmaktadır. Özellikle yere ve yöreye özgü tasarım rehberleri hazırlanması aşamasında, ilgili yerel idarelerin sürecin ana aktörleri olması gerektiği düşünüldügünde bahsi geçen sorunlarla karşılaşacağı açıkça görülmektedir. 
Ülkemizin şehircilik konusunda çok fazla bir gelişim gösteremediğini ve sürecin çok istenen şekilde yönetilemediği, çok farklı çevrelerce kabul edilen bir gerçektir. Öncelikle yeni bir şehircilik yasasının çıkartılması gerekmektedir. Bu yasa içeriğinde planlama, kentsel tasarım ve kentsel tasarım rehberlerinin, farklı yönetmeliklerle veya aynı yönetmelik içerisinde farklı başlıklarla desteklenmesi sürecin işleyişi açısından önemlidir.

Çevre Şehircilik Bakanlığı'nın son birkaç yılda atmış olduğu adımlara bakıldığında, yönelimin bu yönde olduğunu göstermektedir. Bilindiği üzere 2014 yılında yürürlüğe giren Mekânsal Planlar Yapım Yönetmeliği'nde, kentsel tasarım ilk kez bir mevzuat kapsamında değerlendirilmiş ve "Kentsel Tasarım Projelerine Dair Esaslar" başlığı ile mevzuatta ki yerini almış ancak yönlendirici ve açıklayıcı bilgilerle sınırlı tutulmuştur. Yine aynı başlık altında kentsel tasarım rehberi şu şekilde tanımlanmıştır; "Kentsel tasarım projesi doğrultusunda mekânın imge, anlam ve kimlik kazanmasını, estetik ve sanat değerinin yükseltilmesini, yapıların bir uyum içerisinde ve bütünlük oluşturacak şekilde düzenlenmesini amaçlayan ve mekânsal planlama sistematiği içerisinde uygulamaya yönelik kılavuz ve tavsiye niteliğinde kararları içerecek şekilde kentsel tasarım rehberi hazırlanır".

644 sayılı Çevre ve Şehircilik Bakanlığının Teșkilat ve Görevleri Hakkında Kanun Hükmünde Kararname ile Mekânsal Planlar Yapım Yönetmeliği'ne dayanılarak hazırlanan "Çevre ve Şehircilik Bakanlığınca Onaylanacak Kentsel Tasarım Projelerinin Hazırlanmasına ve Değerlendirilmesine İlişkin Yönerge" ile de kentsel tasarım projelerinin kapsamı, detayları hedef ve ilkeleri belirlenmiştir. Bu yönerge kapsamında kentsel tasarım rehberlerine de bir açıklık getirilmiştir. İlgili yönergede kentsel tasarım rehberleri şu şekilde tanımlanmıştır;

"Tasarım mekânının imge, anlam ve kimlik kazanmasını, var olan kimliğin korunması ve kimliğe değer kazandırılmasını, estetik ve sanat değerinin yükseltilmesini, yapıların bir uyum içerisinde ve bütünlük oluşturacak şekilde düzenlenmesini ve bütünde kentsel mekânın kalitesini artırmayı amaçlayan, tasarım ilkeleri ve uygulamaya yönelik alternatifleri ve yazılı-görsel detayları barındıran, uygulamayı yönlendiren belgeyi" ifade eder. Yapılan tanımlamada da görüleceği üzere tasarım rehberlerinin, uygulamayı yönlendirici kriterleri, gerek yazılı gerekse de görsel gösterimlerle desteklediği, ayrıca "yapıların bir uyum içerisinde ve bütünlük oluşturacak şekilde düzenlenmesi" gerektiği ile de yapısal müdahalelere açık olduğu ifade edilmektedir.

Çevre ve Şehircilik Bakanlığı tarafından hazırlanan "Kentsel Tasarım Rehberleri" çalışmasında da ifade edildiği üzere, ilgili yönetmelik ve yönergenin Bakanlığın kentsel dönüşüm ile özel proje alanlarında ele alınacak kentsel tasarım projeleri için bazı yaptırımlar getirmiş olsa da, kentsel tasarım projelerinin bütünlük içinde ele alınması için yeterli görülmemiştir. Başka bir ifade ile, belediyeler için hazırlanmış ve bağlayıcıllı̆̆ olan bir yönetmelik yürürlüğe konulmamıştır.

Buna karşın rehber çalışmalarının, yasal bir zeminde karşılık bulması, uygulanabilirliğinin ve ilgili idarelerce harekete geçme noktasında etkin bir rol üstleneceği bir gerçektir. Ülkemizdeki gerek yerel idareler olsun, gerekse merkezi yönetime bağlı taşra teşkilatları açısından olsun, yeni bir kavramın ve uygulama aracının kısa zamanda algılanıp yürürlüğe koyulabilmesi, ancak mevzuat yaptırımı ile mümkün olabilmektedir. Mevzuatta herhangi bir yaptırımı bulunmayan bir konunun, mevcut idarelerce sadece keyfi olarak algılandığ unutulmamalidır. 


\section{Söke İlçesi’nde Kentsel Yenilemenin Gerekliliğine İlişkin Bulgular}

Türkiye'de mekânsal değişimin yönetilmesi, imar planları ile gerçekleştirilmektedir. Ancak gerekli olan esneklikten uzak ve katı bir çerçeve çizen bu süreç, kentsel alanın değişim ve dönüşümünde yetersiz kalmaktadır. Başka bir deyişle, kentsel alanlardaki değișimin yönetilmesi sürecinde, yasal olarak yapılaşmanın sağlanabilmesi için temel birim parsel olarak karşımıza çıkmaktadır. Parsel olarak tanımlanan bu en küçük birimlerin bir dizi şeklinde yan yana çoğaltılarak adalar oluşturulması ve bu oluşturulan adalara yapılaşma koşulu öngörülerek inşaat haklarının verilmesi ile süreç tamamlanmaktadır. Bu süreç tüm kent çapında benzer şekilde tekrarlayan eylemler bütünü olmakta, bu ise parsellerin oluşturduğu bir kentsel alan yaratmaktadır. Bunun sonucunda tüm kentlerimizde kentleşme süreci benzer karakter göstermekte, kentlerin veya yerleşim birimlerinin kendine özgü yöresel farklılıkları, iklim koşulları, topoğrafik yapısı ve kent kimliğini oluşturan birçok faktör göz ardı edilmektedir.

Aydın ilinin Söke ilçesi, kentsel yenileme alanı olarak belirlediği alan özelinde, yukarıda bahsi geçen olumsuzlukların önüne geçmek amacı ile planlama sürecini tasarım denetimi ile birlikte sürdürme yönünde karar almıştır. Yapılan çalışma kapsamında Söke ilçesinin seçilmesinde ki temel gerekçe ise bu verilen kararın başlangıç aşamasından son aşamaya kadar olan sürecin sorgulanması ve değerlendirilebilir bulunmasıdır.

Söke ilçe merkezindeki yerleşimin, mekânsal gelişimi 2006 yılında yapılan 1/5000 ölçekli Nazım İmar Planı'na kadar, 1/1000 ölçekli Uygulama İmar Planları ile şekillenmiştir. Bu durum ise, ilçe özelinde üst ölçek mekânsal strateji gelişiminin sağlanamamasına ve uygulama ölçeğinde noktasal ve parçacıl plan kararları üretilerek kente dair üst ölçek strateji ve hedeflerden yoksun bir gelişim göstermesine neden olmuştur. İlk kez 2006 yılında onaylanan 1/5000 ölçekli Nazım İmar Planı kararlarında, havaalanı, üniversite kampüs alanı, organize sanayi alanı ve golf turizmini öneren bir yaklaşım getirilmiştir.

$\mathrm{Bu}$ önerilen üst ölçek plan kararları, Çevre ve Şehircilik Bakanlığı'nca onaylanan 1/100.000 ölçekli Çevre Düzeni Planlarında da korunmuş; Üniversite Alanı, Turizm Gelişme Bölgesi, Organize Tarım Bölgesi, Organize Sanayi Bölgesi gibi önerilen arazi kullanım kararları Söke Kentine Metropol Alt Merkez olma işlevini yüklemiştir. Bu öneri kararlar, eğitim, tarım, turizm ve sanayi kenti bileşenlerinin hepsini bünyesinde taşıması anlamında da önemli ve stratejik kararlar olarak kabul görmüştür. Buradaki önemli soru, bu kadar önemli stratejik mekânsal kararların verildiği Söke ilçesinin kent merkezinin bu stratejik mekânsal değişime entegre olabilecek yapıda olup olmadığına ilişkindir. Bu sorunun yanıtını alabilmek için alana ilişkin fiziksel ve sosyo ekonomik analizler yapılmış ve ortaya çıkan sonuçlar kent merkezinin metropol alt merkez olma işlevini yerine getirebilecek vizyonda tekrar biçimlenmesini zorunlu hale getirmiştir. Kent merkezine ilişkin mekânsal değişimin gerçekleştirilmesi için, yöntem olarak kentsel yenileme projesinin hazırlanmasına karar verilmiştir. Bu karar doğrultusunda kentsel yenileme süreci başlatılmış ve bu süreçte kentsel tasarımın etkin bir araç olarak kullanılarak, imar planlarını yönlendirmesi amaçlanmıştır. $\mathrm{Bu}$ amaç doğrultusunda, kente yüklenen çok farklı misyonların, kent merkezi ile ilişkilendirilmesi ve kentin marka değerini yükseltecek mekânsal değişimin gerçekleştirilmesi önem kazanmış ve Söke Belediyesi'nce farklı bir model önerisi geliştirilmiş ve 20.03.2015 ile 16.06.2015 tarihleri arasında 'İmar Planlamasına Esas Kentsel Yenileme Eksenli Fikir Projesi’ düzenlenmiştir. 
Kentin metropoliten alt bölge merkezi olması yönünde, 2025 y1lı için önerilen vizyonun gerçekleşmesi için, kent merkezinin klasik imar planı anlayışı ile ele alınmaması, mekânsal dönüşüm kararlarının öncelikle kentsel tasarım ölçeğinden başlanarak kurgulanması ve bunun sonucunda ortaya çıkacak konsept planın, teknik ve sosyal donatı, ulaşım, ve yoğunluk kararları ile nazım planı yönlendirmesi amaçlanmıştır. Bu doğrultuda, öncelikle 2006 yılında Söke Belediyesi'nce geliştirilen Akıllı Kent Otomasyon Sistemi (AKOS) yardımı ile zemin kat arazi kullanım durumu, kat adetleri, mülkiyet sahipliği, parsel büyüklükleri, ruhsat durumu, imar durumu talepleri, fiziksel ve sosyo-ekonomik analizler gerçekleştirilmiştir. Elde edilen tüm veriler çerçevesinde, hazırlanan 'mekânsal strateji belgesi' ile çalışma alanına özel stratejiler geliştirilmiştir. Bu stratejiler ile öncelikle kentsel alana müdahale bölgeleri, müdahale biçimi ve müdahalede ki öncelikli alanlar tanımlanmıştır.

Beyaz sınır olarak tanımlanmış alan, yapı stoku ve mülkiyet dokusu yenilenecek alan sınırını, sarı çizgi olarak tanımlanan alan yarışma alan sınırını ve kırmızı olarak belirtilen sınır içerisinde kalan alanlar ise yapılaşması durdurulan alanı ifade etmektedir (Şekil 3).

Bu kapsamda, 160 hektarlık alan içerisinde, Söke Belediye Meclisi'nin 08.09.2014 tarih ve 2014/9-148 sayılı meclis kararıyla Cumhuriyet ve Çeltikçi Mahalleleri, 08.09.2014 tarih ve 2014/9-149 sayıl1 Meclis karariyla Konak Mahallesi ve 08.09.2014 tarih ve 2014/9-147 sayılı meclis kararıyla Yenicami Mahallesini kapsayan $1.030 .340 \mathrm{~m}^{2}$ yüzölçümlü bir alanda yapılaşmanın bir yıl süre ile durdurulmasına karar verilmiştir. Söke Belediye Meclisi’nin bu kararları, Aydın Büyükşehir Belediye Meclisi tarafından değerlendirilerek 11.12.2014 günlü toplantısında, kabul edilmiştir.

Daha yaşanılabilir bir Söke için, 2025 vizyonu çerçevesinde kentin metropoliten alt merkez olma hedefi ile örtüşen mekânsal değişim ve gelişiminin sağlanması, yeşil alan, ulaşım, otopark, sosyal donatı ve yapısal sorunların çözümü, Söke Çayı'nın ıslahı ve kente aktif olarak kazandırılması ve yakın çevre ilişkilerinin güçlendirilmesi, kentsel odak noktaları ile birlikte, yarı açık ve açık kentsel mekânlar oluşturulması ve alanının bütünü ile ilişkilendirilmesi doğrultusunda yeni bir kent kimliğinin ilçeye kazandırılması hedeflenmiştir. 


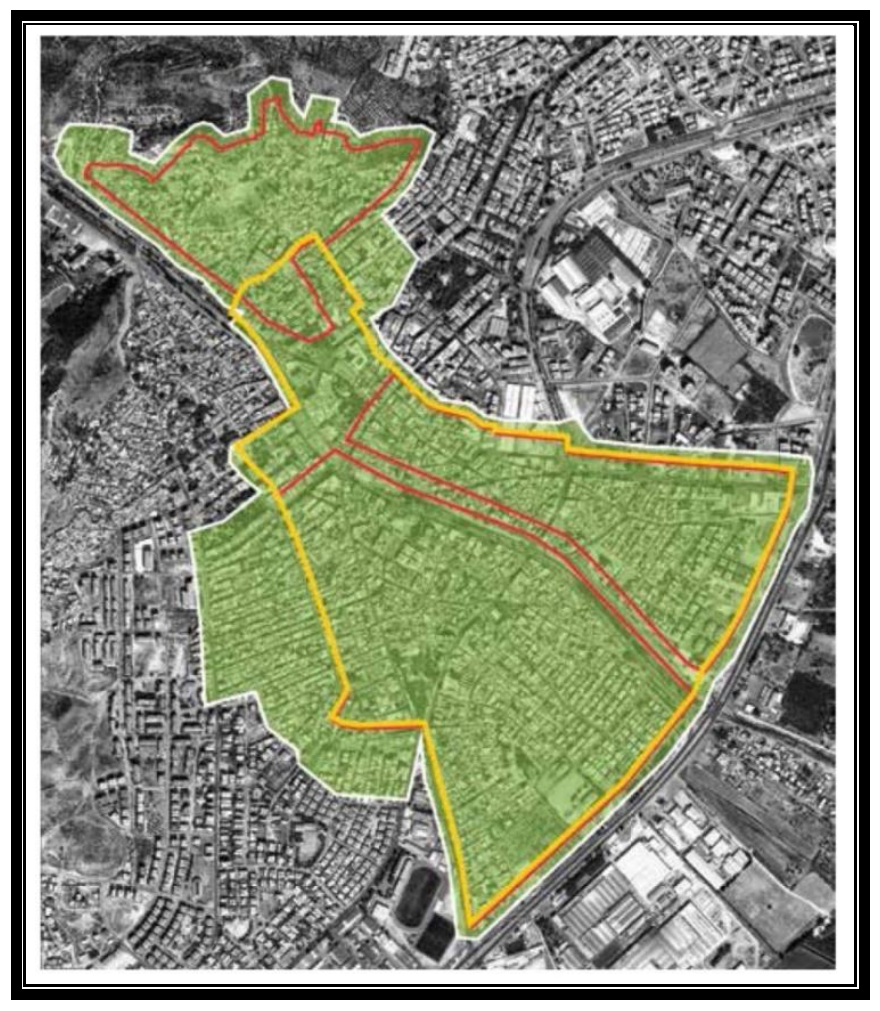

Şekil 3 Mekânsal fiziki değişim sınırları (Söke belediyesi, 2017)

"İmar Planlamasına Esas Kentsel Yenileme Eksenli Fikir Projesi” yarışmasından sonra kentsel tasarım projesi ihale edilmiştir. Hazırlanan kentsel tasarım projesi ilkelerine uygun olarak 1/5000 ölçekli Söke İlçesi, Kent Merkezi ve Çevresi Nazım İmar Planı önerisi Söke Belediyesi'nce hazırlanarak Aydın Büyükșehir Belediyesi'ne sunulmuştur. Daha öncede ifade edildiği üzere hazırlanmış olan bu öneri plan çalışması kent merkezinde yoğun yapılaşmanın bulunduğu alanlarda uygulanamayacak bir plan oluşturduğu gerekçesi ile 11.08.2016 tarih ve 298 sayılı Aydın Büyükşehir Belediye Meclis kararınca uygun görülmemiştir. Büyükşehir Belediyesince hazırlanan 1/5000 ölçekli Söke İlçesi, Kent Merkezi ve Çevresi Revizyon Nazım İmar Planı Aydın Büyükşehir Belediyesi'nin 17.11.2016 tarih ve 424 sayılı kararı ile onaylanmıştır. Bu da Söke Belediyesi'nin kentsel tasarımı araç olarak benimseyerek yaptığı kentsel yenileme projesinin hayata geçmesini engellemiştir. Bu noktada ülkemizde plan onama yetkilerinin pek çok kuruma paylaştırılmış olması hususunun, bu hususta yaşanan sıkıntıların önüne geçme noktasında yeni yasal düzenlemelerle çözülmesi gerekliliğini göstermektedir. Buna paralel olarak, onama yetkisi yerel yönetimlerde olan plan türlerinin de, özellikle büyükşsehir statüsünde olan yerel yönetimlerde, ilçe ve büyükşsehir belediyelerinin farklı siyasi partilerce yönetilmesi veya aralarında yaşanan kısır ve anlamsız çekişmeler neticesinde plan onama yetkilerinin bir yaptırım olarak kullanılması ülkemizdeki planlama ve şehircilik uygulamalarının gelişimine engel olduğu gerçeğidir.

Söke Belediyesi'nce kentsel tasarım projesi kararları ile üretilen 1/5000 ölçekli Nazım İmar Planı'nın, Aydın Büyükşehir Belediyesi’nce uygun görülmemesi, kabul edilen Nazım İmar 
Planı'na uygun olarak hazırlanması gereken 1/1000 ölçekli Revizyon Uygulama İmar Planlarının etaplar halinde hazırlanması yönünde karar verilmesine neden olmuştur (Şekil 4).

Söke Belediyesi'nce 1. Etap olarak belirlenen alan yarışma alanı sınırları dışarısında kalmakla birlikte, yapı stoku ve mülkiyet dokusu yenilenecek alan sınırları içerisinde yer almaktadır. Bu alanın ilk etap olarak belirlenmesinde ki temel neden ise, planlama ve yapılaşma açısından daha az sorunlu görülen bir alan olması yanı sıra yarışma ve kentsel tasarım projesi sınırları dışarısında kalan bir alanda olmasıdır.

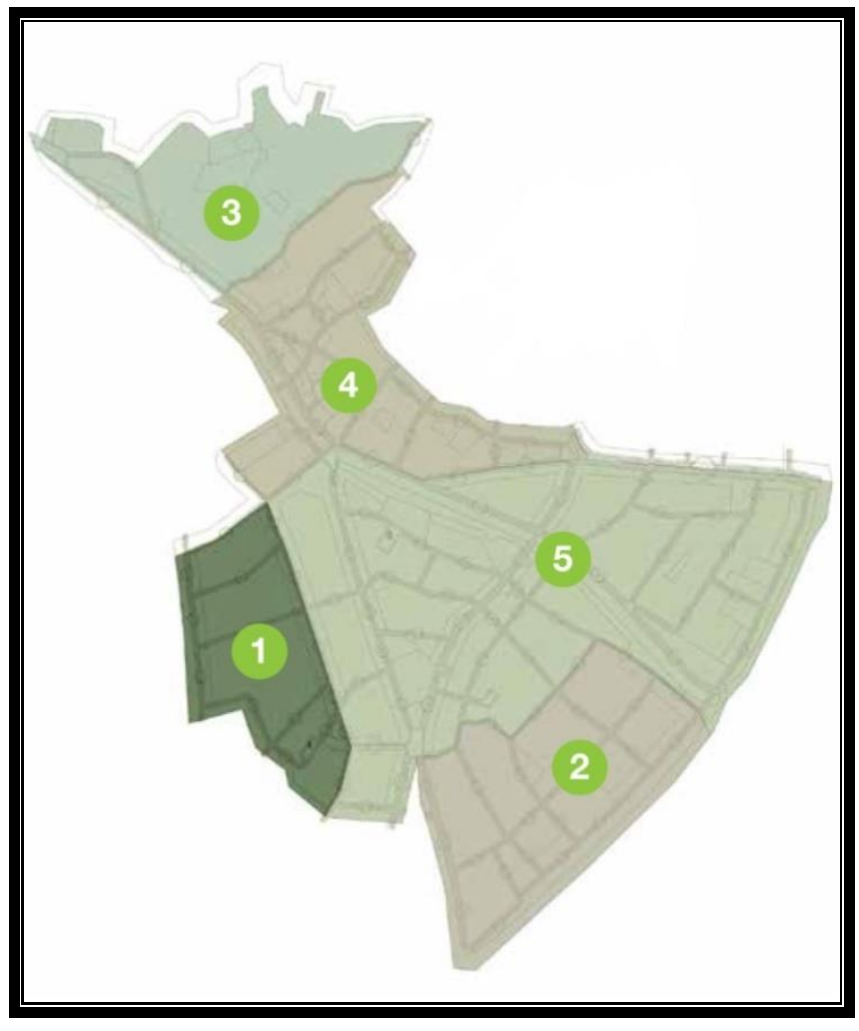

Şekil 4 Söke ilçesi revizyon uygulama imar planı etaplama sınırları (Söke Belediyesi Fen İşleri İmar ve Şehircilik Müdürlügü, 2017)

Bu kapsamda 16 hektar alanı kapsayan Söke İlçesi Kent Merkezi ve Çevresi 1.Etap Revizyon Uygulama İmar Planı hazırlanmış ve onaylanmıştır (Şekil 5).

2. Etap olarak belirlenen 22 hektar alanı kapsayan Söke İlçesi Kent Merkezi ve Çevresi 2.Etap Revizyon Uygulama İmar Planı da tamamlanmış, Söke Belediye Meclisince onaylanmış, Aydın Büyükşehir Belediyesinin onama sürecini beklemektedir (Şekil 6). 


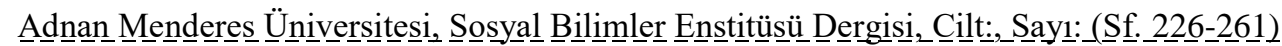

Adnan Menderes University, Journal of Institute of Social Sciences, Vol:, No: (pp. 226-261)
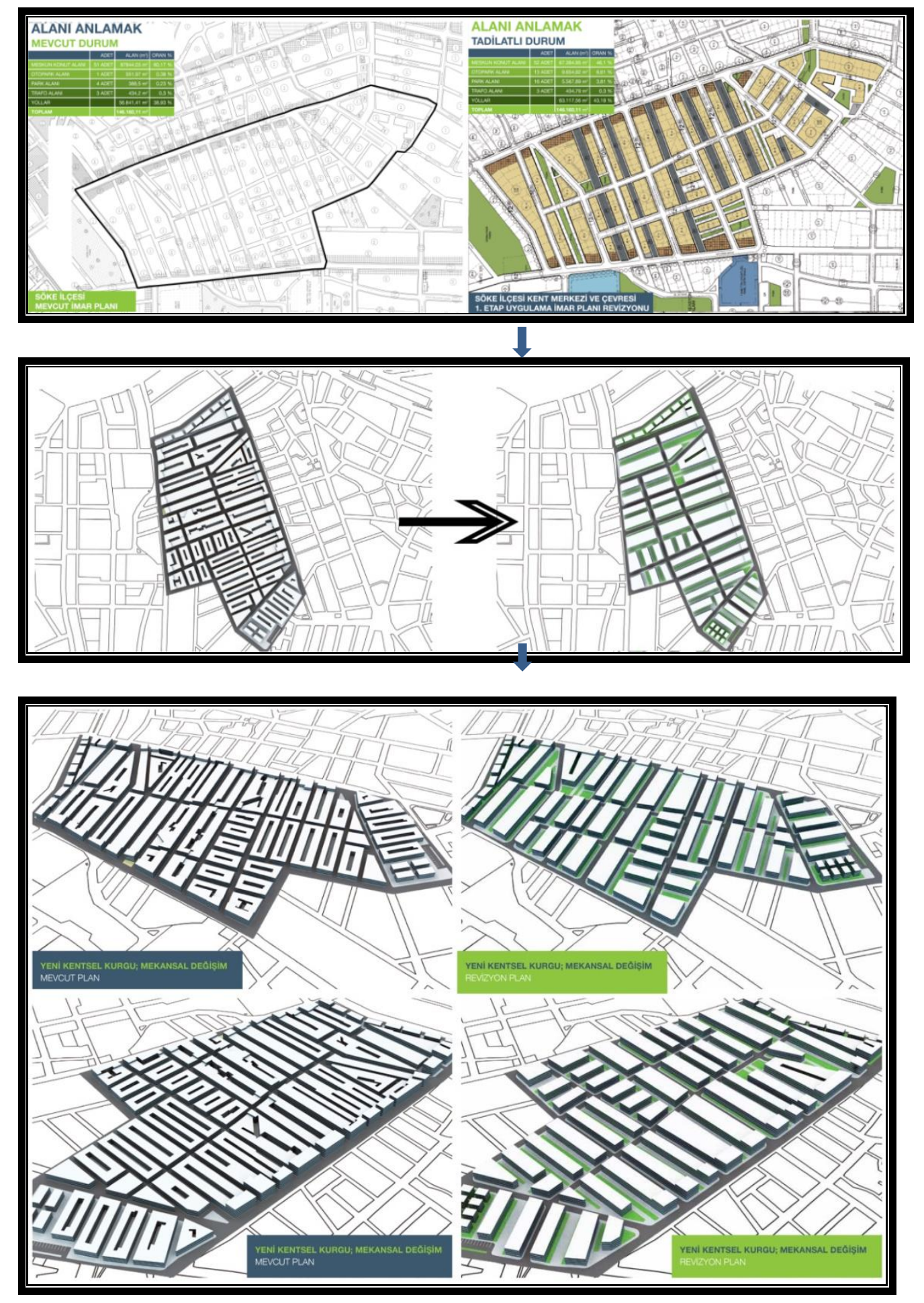

Şekil 5 Söke ilçesi 1.etap revizyon uygulama imar planı mekânsal kurgusu (Söke Belediyesi Fen İşleri İmar ve Şehircilik Müdürlüğü, 2017) 
Adnan Menderes Üniversitesi, Sosyal Bilimler Enstitüsü Dergisi, Cilt:,_Say1:_(Sf. 226-261) Adnan Menderes University, Journal of Institute of Social Sciences, Vol:, No: (pp. 226-261)
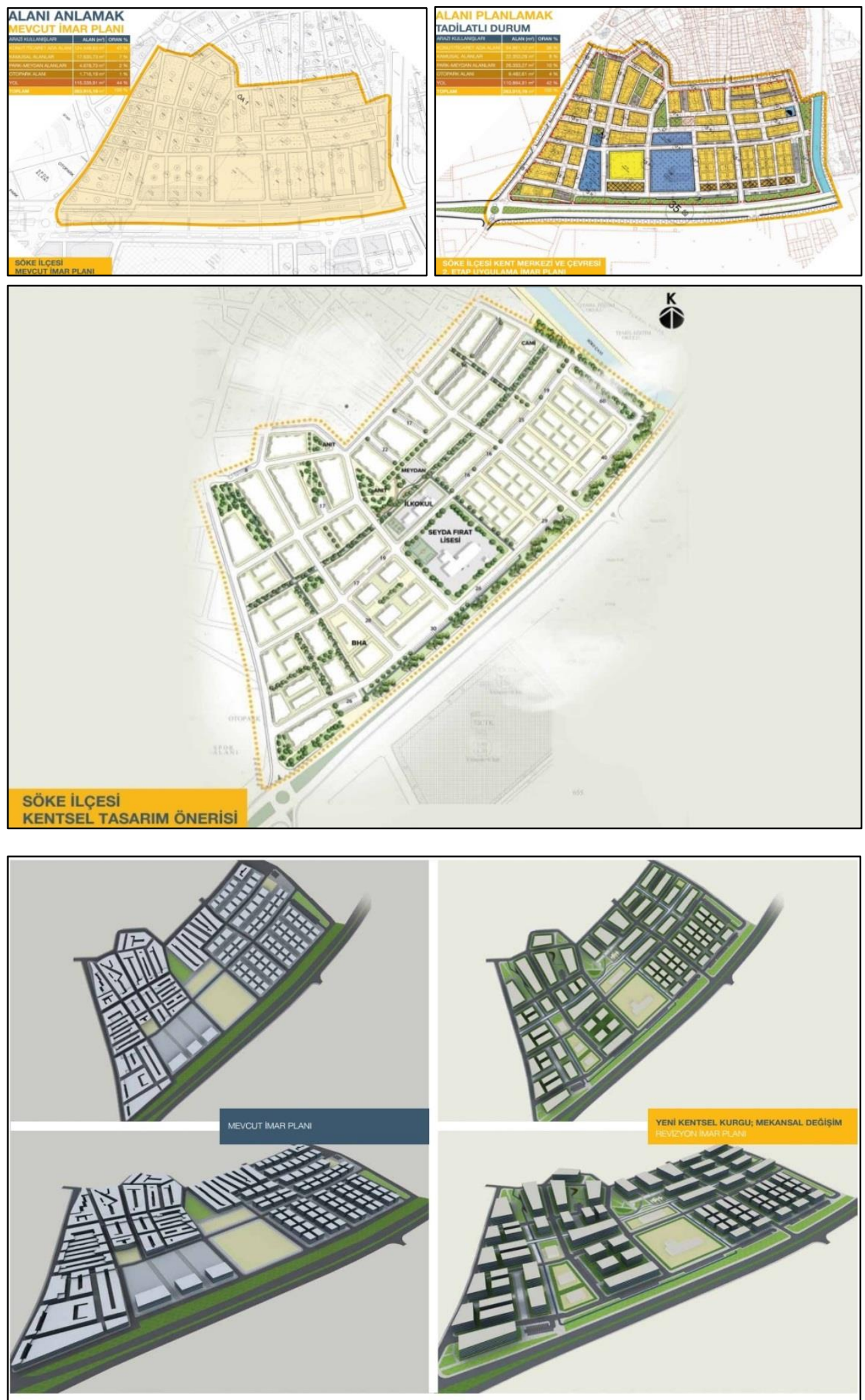
Şekil 6 Söke ilçesi 2.etap revizyon uygulama imar planı mekânsal kurgusu (Söke Belediyesi Fen İşleri İmar ve Şehircilik Müdürlüğü, 2017)

Ülkemizdeki pek çok yerleşimde olduğu gibi Söke ilçesinde de benzer planlama ve yapılaşma süreçlerinin yaşandığı anlaşılmaktadır. İlçe içerisinde ki merkezi konumda yer alan ve yenileme alanı olarak tanımlanan alan için yapılmış olan meri planlardaki planlama yaklaşımının, mevcut mevzuatların izin verdiği ölçüde mekânsal gelişimi sağladığı görülmektedir. Ancak daha önce de ifade edildiği üzere, mülkiyet dokusunun korunmasına yönelik oluşturulan imar adalarının ve bu imar adalarında önerilen yapılaşma koşullarının ve bunun devamında estetik ve çevre ile uyumlu yapılaşma sürecinin sağlıklı yürütülememesi gibi temel nedenlerin yaşam standardını yükseltecek yaşanılabilir kentsel alanların oluşturulmasına engel olduğu görülmektedir. Özellikle mevcut dokuda kalan buna benzer alanlarda, kadastral mülkiyet hatları imar parseli gibi işlevlendirilmekte ve bununla birlikte 3194 sayılı İmar Kanunu'nun 15. ve 16. Maddelerine göre uygulama yapılması idarelerin tercih ettiği bir seçenek olarak mevzuat içerisinde yer bulmaktadır. Ancak bu tür uygulamalar diğer bir yandan da yerleşmede yaşanan yapısal, çevre, ulaşım ve donatı sorunlarının da temel nedenini oluşturmaktadır. Eğitim, sağlık, kültürel tesisi vb gibi donatı alanlarının sınır çizgilerinin de kadastral mülkiyet sınırları ile tanımlanması, şekilsiz ve işlevsiz alanların ortaya çıkmasına neden olmaktadır. Genel anlamda planlama ve tasarım ilkelerinden çok, mülkiyet esaslı planlama ve yapılaşma kurguları tüm bu olumsuz süreçlerin temel nedeni olarak karşımıza çıkmaktadır. Merkez lokasyonlardaki yerleşik doku içerisinde önerilen bitişik nizamlı ve yüksek emsal değerine sahip yapılaşma koşulları ile kadastal mülkiyet esaslı yapılaşma süreci, hem çarpık yapılaşmanın, hem de yeterli donatı alanlarının ayrılamamasının temel nedenini oluşturmaktadır. Sonuç olarak Söke örneğinde görüldüğü üzere tüm bu olumsuz süreçlerin temel nedenlerinin tespit edilerek, söz konusu alanda bütüncül bir yaklaşımla kentsel yenileme eyleminin tasarım ilkeleri ile birlikte kurgulanması, bir başka ifadeyle planlama sürecinin yeniden tariflenmesi, bu tür alanların planlanmasında önemli bir deneyim oluşturmuştur.

Bir diğer önemli konu ise, projeden sonraki sürecin yönetilmesi ile ilgilidir. Yerel yönetimler sürecin merkezinde olmalı, halkı yönlendirmeli ve bilgilendirmeli, uygulama aşamasında halk ile geliştirici arasında bir köprü görevi görmelidir. Aynı zamanda yerel yönetimler, katılımcı seviyesinin arttırılması ve uzlaşma sürecinde de etkin rol almalıdırlar. Bu kapsamda, sonraki süreçte Söke Belediyesi yerel halkı, yenileme alanı içinde yer alan taşınmazı ile ilgili bilgilendirmeli, gerekirse ikna etmeli, yatırımcıyı ise alana yatırım yapması konusunda teşvik etmek üzere bilgilendirmelidir. 


\section{Sonuçlar ve Öneriler}

Ülkemizde kentsel yenileme ve kentsel tasarım kavramları üzerine, yeterince açık ve net tanımlamaların mevcut mevzuatlarımızda yer almaması sürecin doğru olarak yürütülemediğini göstermiştir. Bu kapsamda, yeni bir şehircilik yasasının hazırlanması ve bu yasa çerçevesinde, planlama, kentsel yenileme, kentsel dönüşüm, kentsel tasarım ve kentsel tasarım rehberlerine ilişkin kavramların birbirleriyle ilişkilendirilerek yasal bir düzlemde karşılığının olması gerekmektedir. Kentsel tasarımın tüm boyutlarıyla ele alındığı ve planlamanın içerisinde konumlandırıldığı bir yasal düzenlemeye ihtiyaç duyulmaktadır.

Kentsel yenileme ve kentsel tasarım gibi kavramlara ilişkin uygulama süreçlerinin baş aktörleri yerel yönetimler olarak görülmektedir. Ancak yerel yönetimlerin, şehir yenilemeyi, kısıtlı bir çerçevede ele almaları ve klasik imar planı uygulaması olarak görmeleri gerçek anlamda bir şehirsel yenileme uygulamasının yapılamamasına neden olmaktadır. Yerel idareler, kentsel yenileme uygulamalarına finansal kaynak yaratmada sıkıntı yaşamakta ve bu nedenle yenileme uygulamalarına temkinli yaklaşmaktadırlar. Böylelikle, konusunda uzman personel eksikliği, kaynak yaratamama ve kavramların tam alarak net anlaşılamaması ve alt yapı eksiklikleri (rezerv alan vb) yerel idarelerce genel manada şikâyet konusu da olan niteliksiz ve sağlıksız yapılaşma, çevre koşullarının iyileştirilememesine ve yenilenememesine neden olmaktadır.

Bu kapsamda kentsel yenileme yapılacak alana ilişkin, fiziksel müdahalelerin kentsel tasarım projeleri ile desteklenmesi gerekmektedir. Yörede yaşayanların beklentileri iyi analiz edilmeli ve katılımcı bir süreçle hedefe ulaşmaya yönelik stratejiler geliştirilmelidir. Kentsel mekânda, kentsel yenileme projeleri ile yapılacak olan iyileștirmeler, bölgede yaşayanlarca da desteklenmeli ve yaşam kalitesinin arttırılması ve bölgenin tekrar kente kazandırılması yönünde ilkeler belirlenmelidir. Kentsel açık alanların ve yaya sirkülasyonunun kent parçasına sosyal ve ekonomik anlamda katkı sağlayacağı bilinmektedir. Bu nedenle güvenli yaya koridorları oluşturulmalı, kentsel yenileme projelerinde etkin olarak hayata geçirilmelidir. Bölge içerisinde karma kullanımların desteklenmesi, ticari çeşitliliğin arttırılması ve tüm bunlar planlanırken yaya ve toplu ulaşım imkânlarının da etkin hale getirilmesi hedefe ulaşma noktasında önemli kriterler olarak karşımıza çıkmaktadır.

Kentsel yenileme projesinin, belirlenen kentsel tasarım ilkeleri ile birlikte yürütülmesinin Söke ilçesi açısından önemli bir gelişim ve değişim sürecini başlattı̆̆g görülmektedir. Alana ilişkin yapılmış olan tüm araştırma ve analizler sonucunda, tespit edilen sorunlara alternatif çözüm önerileri gerçekleștirilerek, daha yaşanılabilir, yaşam kalitesi yüksek, yeterli yarı açık ve açık kamusal alanların yaratıldığı, yaya ve taşı ulaşım akslarının ayrıştırılarak tanımlandığı, yeterli ve süreklilik arz eden açık aktif yeşil alanların önerildiği bir yaklaşımın, yerel ekonomiye de belirgin bir şekilde katkı sağlayacağı bilinmektedir. Bu nedenle kentsel tasarımın sadece fiziksel çevrenin iyileştirilmesi olarak kalmayacağı, Söke İlçesi'nin sosyal ve ekonomik gelişimine de olumlu katkı sağlayacağı gerçeği göz ardı edilmemelidir.

\section{Planlamaya yönelik öneriler:}

- Faklı ölçeklerdeki planlama çalışmalarının yapımının ve onanmasının, yerel idarelerin sorumluluğunda olan nazım ve uygulama imar planlarının büyükşehir ve ilçe belediyeleri arasındaki yetki dağılımı nedeniyle, yönetimler arası çatışmaların ve görüş ayrılıklarının oluşması durumunda süreci uzattığı hatta 
durdurduğu bilinmektedir. Büyükşehir Belediyelerinin yetki ve sorumluluğunda olan 1/5000 ile 1/25000 arasındaki her ölçekte nazım imar planını yapılması, yaptırılması, onaylanması ve uygulamaya konulması süreci, ilçe belediyelerinin kentler için öngördüğü sorunlu alanlara ilişkin mekânsal değişim kararlarını uygulayabilmesini zorlaştıran bir etken olarak karşımıza çıkmaktadır. Bu karmaşanın ortadan kaldırılması yönünde yeni yasal düzenlemelerin yapılması gerekmektedir.

- Üst ölçekli Çevre Düzeni Planlarında kentte dair önemli mekânsal stratejik kararların öngörüldüğü durumlarda, o kentin yerleşik alanına ait plan kararlarının bu öngörüler doğrultusunda yenilenmesinin ve bu anlamda alt ölçek planları yönlendirecek plan notlarının düzenlenmesinin ve bu sürecin yasal zeminde karşılık bulmasının önemli olacağı düşünülmektedir.

- İmar planları dâhilinde parsellerin tanımlanması ve bu tanımlama çerçevesinde öneri kütle tasarımlarının ve çevresiyle olan ilişkilerin belirlenmesi yönünde, şehir plancılarının sürecin içerisinde olması ve bu doğrultuda yasal düzenlemelerin yapılması yerinde olacaktır. Uygulama imar planlarının sadece fonksiyon belirleyen ve yapılaşma koşulu ve yapı yaklaşma sınırı belirleyen kısır döngüden kurtulması, kentsel mekânın değişim ve dönüşümünün sağlanması yönünde en önemli aktör olan planlama kavramının çerçevesi genişletilmeli, parselasyon ve mülkiyet hatları ile birlikte öneri yapı tipolojilerinin de dahil edilmesi zorunlu hale gelmelidir.

- Kentsel yenileme projeleri mevcut şehir planı ile uyumlu ve bütüncül bir yaklaşımla ele alınmalı, gerektiğinde uygulama etapları belirlenerek yürütülmelidir. Ancak öncelikle, problemli alana ilişkin, tespit edilen sorunlara çözüm bulmaya yönelik hazırlanan, güncel ve gelecekteki beklentileri karşılama hedefi ile hazırlanıp onaylanan plan revizyonları ve kentsel tasarım projeleri bütünsel bir yaklaşımla ele alınmalıdır. Böylelikle, uygulama aşamasında yaşanacak olan gerek finansal, gerekse de teknik problemlerin ortaya çıkması hali düşünülmeli, uygulamanın etaplar halinde plan konseptine göre gerçekleştirilmesinin olası sorunları minimize edeceği unutulmamalıdır. Kaldı ki büyük alan gerektiren kentsel yenileme çalışmalarında, bazı alanlara öncelik verilmesi, başarılı bir şekilde uygulanıp sonuçlanan yenileme alanına ilişkin bir etabın diğer etaplardaki mülkiyet sahiplerini ve yatırımcıları teşvik etme hususunda önemli bir eşik olacağı kabul edilmelidir.

- Kentsel yenileme, planlama ve kentsel tasarım süreçlerinin birlikte yürütülmesi, bütüncül bir çerçevede sürdürülebilirliğin sağlanması, yaşam kalitesinin arttırılması, nitelikli ve yaşanılabilir kentsel alanların oluşturulması yönünde ilkesel kararların alınması son derece önem arz etmektedir. Kentleşmeye yapılar üzerinden değil, yaşanabilirlik kavramı üzerinden bakıldığında, yenilemenin sosyal etkilerinin de ne kadar önemli olduğu unutulmamalıdır. 


\section{Mevzuata yönelik öneriler:}

- Ülkemizde, kentsel yenileme 5366 sayılı "Yıpranan Tarihi ve Kültürel Taşınmaz varlıkların Yenilenerek Korunması ve Yaşatılarak Kullanılması Hakkında Kanun" kapsamında tanımlanmış olup, kültür ve tabiat varlıklarını koruma kurullarınca sit alanı olarak tescil ve ilan edilen bölgeler ile bu bölgelere ait koruma alanlarını kapsamaktadır. Kentsel yenileme sadece sit alanları veya koruma alanları ile sınırlandırılmamalıdır.

- Geniş kapsamlı yeni bir şehircilik yasası çıkartılmalı, bu yasa içerisinde planlama, kentsel tasarım, kentsel dönüşüm ve yenileme kavramlarına ilişkin tanımlamalar birlikte değerlendirilerek oluşturulmalı ve yönetmeliklerle desteklenmelidir. Nitekim, Çevre ve Şehircilik Bakanlığı tarafından hazırlanan "Kentsel Tasarım Rehberleri” çalışmasında da, Kentsel Tasarım Yönetmeliği'nin hazırlanması konusu kapsayıcılık bağlamında en etkin yol olarak kabul edilmiştir.

- Kentsel yenileme bir planlama süreci olması nedeniyle, yerel idarelerde olan plan onama yetkileri yeniden düzenlenmelidir. Planlar belediye meclislerine sunulmadan önce, konusunda uzman ve yetkin bir kurul tarafindan incelenmeli ve önerileri değerlendirilmelidir.

- Yerel yönetimlerin kurumsal yapılanmalarında, kentsel tasarım müdürlüklerine yer verilmeli ve bu müdürlüklerde ki yetkili birim müdürünün ve çalışanlarının mesleki yeterlilik ve yetkinlik ölçütü yasal düzenlemelerle belirlenmelidir.

\section{Yönetim ve stratejiye yönelik öneriler:}

- Kaynak yaratma konusunda stratejiler belirlenmeli, farklı modeller ortaya koyularak uzlaşmacı ve katılımcı bir anlayışla sürecin yönetilmesi sağlanmalıdır.

- Uzlaşma sürecinde katılımcı seviyesi arttırılmalı, uzlaşma kültürü oluşturulmalıdır. Proje sonrası ortaya çıkan değer artışının nasıl paylaştırılacağı konusu belirlenmelidir. Bu kapsamda değer artışının eşitlik ilkesi çerçevesinde ve kamu yararı gözetilerek paylaşımı esas alınmalıdır.

- Projeyi gerçekleştirecek aktörler önceden belirlenmelidir. Bu aktörler merkezi yönetim-yerel yönetim, özel sektör-yerel yönetim, yerel yönetim-mülk sahipleri vb gibi farklı alternatiflerde değerlendirilmeli ve en uygun ortaklık modeline karar verilmelidir.

- Yerel yönetimlerin kentsel yenileme sürecinde baş aktör olarak yer almasının ve yenileme alanında rol sahibi olan diğer aktörleri örgütlemesinin, sürecin başarıya ulaşmasındaki en büyük etken olduğu göz ardı edilmemelidir. Tüm çalışmalar katılımcı anlayışla yönetilmeli ve yürütülmelidir. 
Adnan Menderes Üniversitesi, Sosyal Bilimler Enstitüsü Dergisi, Cilt:, Say1:(Sf. 226-261)

Adnan Menderes University, Journal of Institute of Social Sciences, Vol:, No: (pp. 226-261)

Tüm bu öneriler kapsamında, kentsel yenileme, planlama ve kentsel tasarımın birlikte ve bütüncül olarak değerlendirilmesi, katılımcı ve şeffaf yürütülen bir süreç sonrası yaşam kalitesinin arttırılması ortak hedef olarak benimsenmelidir. 


\section{Kaynaklar}

ANDERSEN H. S. (1999). Housing Rehabilitation and Urban Renewal in Europe: A CrossNational Analysis of Problems and Policies, in the Housing Renewal In Europe, eds: Andersen H. S. And Leather P., The Policy Press, Great Britain, 241-277.

AUBÖCK, M. (1996). Open Spaces: The City, Planbox Edition, Wien.

ATALIK G. ve diğ. (1985). Şehircilik. İstanbul: İTÜ Matbaas1

GÜNAY, B. (1999).Urban Design is a Public Policy. ODTÜ Mimarlık Fakültesi Yayınları, Ankara.

HASOL D. (1998). Ansiklopedik Mimarlık Sözlüğü. İstanbul: Yem Yayınları.

KELEŞ, R. (1980). Kent Bilim Terimleri Sözlüğü. Ankara: TDK Yayınları.

T.C ÇEVRE VE ŞEHIRCIILİK BAKANLIĞI. (2016). Kentsel Tasartm Rehberleri. Cilt I-IIIII. İstanbul: Çevre ve Şehircilik Bakanlığı Yayını

SÖKE BELEDIYESİ. (2017). Imar Planlamasına Esas Kentsel Yenileme-Dönüşüm Eksenli Söke Kent Merkezi ile Söke Çayı Çevresi Kentsel Tasarım Projesi Raporu. Fen İşleri Müdürlüğ̈̈, Söke.

SÖKE BELEDIYESİ FEN İȘLERİ İMAR VE ŞEHIIRCILIKK MÜDÜRLÜĞÜ. (2017). Söke İlçesi Kent Merkezi ve Çevresi 1. Etap Uygulama İmar Planı Revizyonu. Fen İşleri Müdürlüğü, Söke.

TEKELİ İ. (1998). Türkiye'de Cumhuriyet Döneminde Kentsel Gelişme ve Kent Planlaması, 75 Yılda Değişen Kent ve Mimarlı, Tarih Vakfı Yayınları, İstanbul. 